\title{
A new Dactylopisthes Simon, 1884 from the Caucasus (Aranei: Linyphiidae)
}

\author{
Новый вид рода Dactylopistbes Simon, 1884 с Кавказа \\ (Aranei: Linyphiidae)
}

\begin{abstract}
A.V. Tanasevitch
A.B. Танасевич

A.N. Severtsov Institute of Ecology and Evolution, Russian Academy of Sciences, Leninsky prospekt 33, Moscow 119071, Russia. E-mail: tanasevitch@gmail.com

Институт проблем экологии и эволюции РАН им. А.Н. Северцова, Ленинский проспект 33, Москва 119071, Россия.

KEY WORDS: spiders, Erigoninae, new species, highlands, Karachay-Cherkessia, Russia.

КЛЮЧЕВЫЕ СЛОВА: пауки, Erigoninae, новый вид, высокогорья, Республика Карачаево-Черкесия, Россия.
\end{abstract}

ABSTRACT. A new species, Dactylopisthes khatipara sp.n., is described based on a single male from the highland North Caucasus. The new species is most similar to the arcto-boreo-montane $D$. video (Chamberlin et Ivie, 1947), but is well distinguished by the shape of the palpal tibia, as well as by structural details of the distal suprategular apophysis and the embolic division. The genus Dactylopisthes Simon, 1884 is new to the fauna of the Caucasus. The female described by Denis [1955] as the corresponding sex for Diplocephalus culminicola Simon, 1884 actually belongs to another species of an unidentified genus.

РЕЗЮМЕ. По единственному самцу из высокогорий Северного Кавказа описан новый вид Dactylopisthes khatipara sp.n. Вид близок арктоборео-монтанному D. video (Chamberlin et Ivie, 1947), от которого хорошо отличается формой голени пальпы, а также деталями строения дистального отростка супратегулюма и эмболюсного отдела. Род Dactylopisthes Simon, 1884 впервые отмечен в фауне Кавказа. Самка, описанная Denis [1955] как Diplocephalus culminicola Simon, 1884, в действительности относится к другому, пока неясному роду.

\section{Introduction}

The small Erigoninae genus Dactylopisthes Simon, 1884 is currently known to comprise seven species [World Spider Catalog, 2016], but the generic attribution of D. separatus Zhao et Li, 2014, described from females from the Yunnan Province, China [Zhao, Li, 2014], requires confirmation. Among congeners, three species show a Central Asian pattern of distribution: $D$. diphyus (Heimer, 1987), D. locketi (Tanasevitch, 1983) and D. mirabilis (Tanasevitch, 1985); further two species are European - Ancient Mediterranean: D. digiticeps (Simon, 1881), D. mirificus (Georgescu, 1976), while D. video (Chamberlin et Ivie, 1947) is East Palaearctic - West Nearctic.

The description of a new Dactylopisthes from the high altitudes of the northern macroslope of the Caucasus Major is the subject of the current paper. This is the first record of Dactylopisthes in the fauna of the Caucasus.

\section{Material and methods}

This paper is based on material collected in 1987 by V.G. Onipchenko from the highlands of the Teberda Biosphere State Nature Reserve, Karachay-Cherkessia Republic, North Caucasus. The type specimen is deposed in the collection of the Zoological Museum of the Moscow State University, Moscow, Russia.

The specimen was collected by pitfall trapping, preserved in $70 \%$ ethanol and studied using a MBS-9 stereo microscope. The sequence of leg segment measurements is as follows: femur + patella + tibia + metatarsus + tarsus. All measurements are in mm. Scale bars in the figures correspond to $0.1 \mathrm{~mm}$ unless indicated below the line.

The terminology of genitalic structures follows that of Merrett [1963] and Hormiga [2000]. The following abbreviations are used in the text and figures: DSA - distal suprategular apophysis; EP - embolus proper; MNHN — Museum National d'Histoire Naturelle, Paris; MM - median membrane; MRA median radical apophysis; MSA - median suprategular apophysis; $\mathrm{R}$ - radix; TmI — position of metatarsal trichobothrium. 


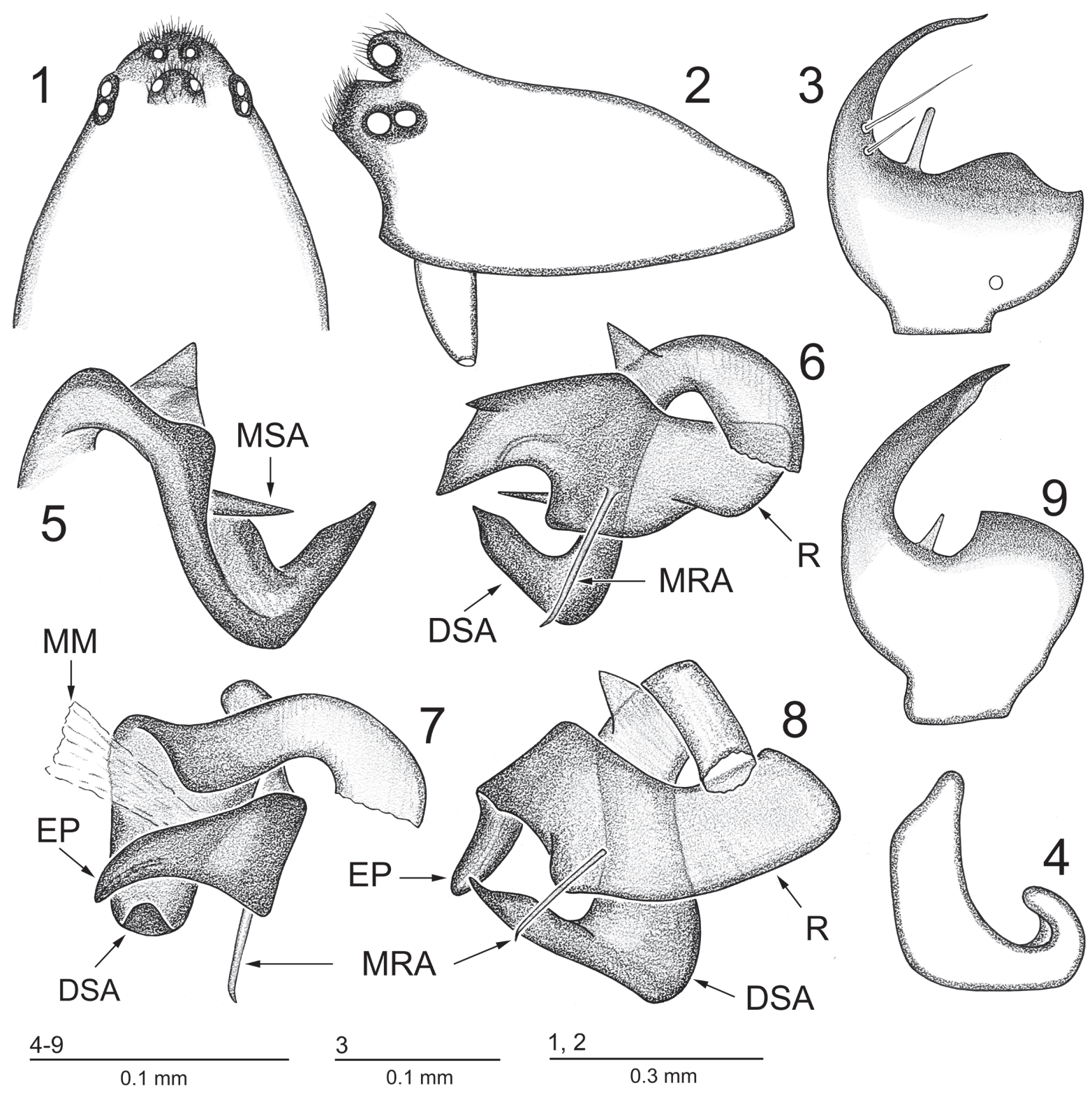

Figs 1-9. Carapace and right palp details of Dactylopisthes khatipara sp.n., holotype (1-8), and $0^{7}$ syntype of Diplocephalus culminicola Simon, 1884 (9). 1, 2 - carapace, dorsal and lateral views, respectively; 3, 9 - palpal tibia, dorsal view; 4 - paracymbium; 5 - distal suprategular apophysis; 6-8 - distal suprategular apophysis and embolic division, different aspects.

Рис. 1-9. Карапакс и детали строения правой пальпы Dactylopisthes khatipara sp.n., голотип (1-8) и Diplocephalus culminicola Simon, 1884, синтип О (9). 1,2 - карапакс, соответственно сверху и сбоку; 3,9 - голень пальпы, вид сверху; 4 - парацимбиум; 5 - дистальный отросток супратегулюма; 6-8 - дистальный отросток супратегулюма и эмболюсный отдел, различные аспекты.

\section{Description}

\section{Dactylopisthes khatipara sp.n.}

Figs $1-8$.

HOLOTYPE OT, RUSSIA, Caucasus, Karachay-Cherkessia Republic, Teberda Nature Reserve, Mt Malaya Khatipara, 2700-2800 m a.s.l., alpine meadow, 9-15.VIII.1987, leg. V.G. Onipchenko.

ADDITIONAL TYPE MATERIAL EXAMINED. Diplocephalus (now labeled as Streptosphaenus, but originally described in

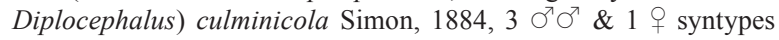

(MNHN, No: AR 12101, labeled "paralectotypes", but no lectotype designation seems to have ever been published).

NAME. The specific epithet is a noun in apposition, referring to the terra typica, Mount Malaya Khatipara.

DIAGNOSIS. The new species is characterized by the presence of a small dorso-apical process on the palpal tibia, as well as by the shape of the radical apophysis.

DESCRIPTION. Male. Small Erigoninae spider, total length 1.18. Carapace (Figs 1-2) 0.63 long, 0.45 
wide, dark brown, with a polygonal median spot and a darker margin. Anterior part of carapace slightly protruded forwards, head part with a small rounded elevation carrying posterior median eyes. Sulci absent. Chelicerae 0.23 long, not modified. Legs pale brown. Leg I, 1.28 long $(0.38+0.13+0.28+0.25+0.24)$, IV, 1.51 long $(0.44+0.13+0.39+0.30+0.25)$. Chaetotaxy unclear: spines lost or reduced. Metatarsi I-III each with a trichobothrium. TmI, 0.49. Both palps inflated and dissected for investigation (Figs 38): Palpal tibia with a large, falcate, prolateral apophysis and a short, narrow, dorso-apical process. Paracymbium simple, L-shaped. Distal suprategular apophysis strongly developed, S-shaped, with a styletshaped process near middle (MSA in Fig. 5). Embolic division twisted, embolus proper relatively short and thick. Radix carrying a thin, needle-shaped process (MRA in Figs 6-8), slightly bent apically. Abdomen 0.66 long, 0.50 wide, black.

Female unknown.

TAXONOMIC REMARKS. Dactylopisthes khatipara sp.n. is very similar to the arcto-boreo-montane D. video (Chamberlin et Ivie, 1947), and might have been its derivate developed into a separate species either in situ or ousted from the north and survived in the Caucasian mountains during the Pleistocene glaciations. The new species differs from $D$. video by the presence of the small, finger-shaped, dorso-apical process on the palpal tibia, as well as by the shape of the distal suprategular apophysis and the embolic division. The needle-shaped process arising directly from the radix in $D$. khatipara sp.n. is somewhat similar to that of $D$. video, but longer, of the same thickness throughout and ends with a slightly bent sharp point.

NOTE. The shape of the palpal tibia in D. khatipara sp.n. is very similar to that of Diplocephalus culminico- la Simon, 1884, from France (cp. Fig. 3 \& 9). The latter species was originally described from the male [Simon, 1884], the female was described much later by Denis [1953]. However, based on the figures of the epigyne provided by Denis [op. cit., figs 6-7], the female specimen belongs to another species of an undefined genus. The examination of the female syntype of $D$. culminicola shows that its epigyne is typical of the genus, i.e. supplied with a bisected ventral plate.

DISTRIBUTION. Known from the type locality only.

ACKNOWLEDGEMENTS. I am very grateful to V.G. Onipchenko whose collection has been used here. Special thanks go to Christine Rollard (MNHN) for providing the type material of Diplocephalus culminicola, and to Sergei Golovatch (Moscow, Russia) who checked the English of an advanced draft.

\section{References}

Denis J. 1953. Araignées des environs du Marcadau et du Vignemale (Hautes-Pyrénées) // Bulletin de la Société d'Histoire naturelle de Toulouse. T.88. Fasc.1-2. P.83-112.

Hormiga G. 2000. Higher level phylogenetics of erigonine spiders (Araneae, Linyphiidae, Erigoninae) // Smithsonian Contributions to Zoology. No.609. P.1-160.

Merrett P. 1963. The palpus of male spiders of the family Linyphiidae // Proceedings of the Zoological Society of London. Vol.140. P.347-467.

Simon E. 1884. Les arachnides de France. Paris. T.5. P.180-885.

World Spider Catalog. 2016, Natural History Museum Bern. Online at http://wsc.nmbe.ch. Version 17.5 (accessed in December, 2016).

Zhao Q.Y., Li S.Q. 2014. A survey of linyphiid spiders from Xishuangbanna, Yunnan Province, China (Araneae, Linyphiidae) // ZooKeys. Vol.460. P.1-181.

Responsible editor K.G. Mikhailov 